\title{
Numerical and statistical evaluation of nitric oxide effect on leaf anatomy of Triticum genotypes under salinity stress
}

\begin{abstract}
Bread wheat (Triticum aestivum L.) with a very high economic value and great importance for human consumption is extensively cultivated worldwide. However, the wheat genotypes used experience significant yield loss when exposed to salinity conditions due to the fact that salt is a factor that affects plant metabolism. Nitric oxide, a well-known signalling molecule due to its therapeutic effects on human but produced internally also by plant species, can be utilized to ameliorate the adverse effects of the salinity stress conditions of plants. In this study, the changes caused by external nitric oxide applications on leaves anatomy of two bread wheat genotypes exposed to salinity stress were determined. The results were evaluated statistically by using numerical data obtained from the anatomical measurements.
\end{abstract}

Keywords: anatomy, nitric oxide, numerical Triticum leaves, wheat
Volume 8 Issue 4 - 2020

\author{
Bahattin Bozdağ,' Ali Özdemir, ${ }^{2}$ Mehmet \\ Hamurcu, ${ }^{3}$ Canan Özdemir,' Erdoğan E \\ Hakkı, ${ }^{3}$ Sait Gezgin ${ }^{3}$ \\ 'Department of Biology, Science and Art Faculty, Celal Bayar \\ University, Turkey \\ ${ }^{2}$ Department of Mathematics, Science and Art Faculty, Celal \\ Bayar University, Turkey \\ ${ }^{3}$ Department of Soil Science and Plant Nutrition, Faculty of \\ Agriculture, Selçuk University, Turkey
}

Correspondence: Canan Özdemir, Department of Biology, Science and Art Faculty, Celal Bayar University, Manisa, Turkey, Tel +9053366I 6373, Email cozdemir ! @gmail.com

Received: July 31, 2020 | Published: August 19, 2020

\section{Introduction}

Cultivated plants such as bread wheat with a poor gene pool do not have extensively different genotypes in terms of their tolerance to biotic and abiotic stress conditions. Under abiotic stress conditions such as drought and salinity stress, genetic diversity of the plant species is expected to provide a valuable repertoire from wild wheat species for tolerance to the stress of interest. A number of defense mechanisms have been developed by cultural crops against free oxygen radicals developed under stress conditions. Nitric oxide (NO) is a simple endogenous component of human biology, but effective also in other species. It also has the potential to be used against the external stresses experienced by crop plants, more specifically on wheat exposed to salinity. NO may be produced in different plant species and organs for any threat caused by environmental stresses, either be biotic or abiotic factors. ${ }^{1}$ In literature, in the studies conducted with different crop plants (peas, beans, corn) under abiotic stress conditions, nitric oxide (NO) has been found to increase the stress tolerance level of the plant. ${ }^{2}$ However there are many studies about the physiological effect of $\mathrm{NO}^{3-8}$ only few studies focus on the anatomical effects of NO on cultivated plants. ${ }^{9-11}$ In one of the recent studies that reveals the effects of NO on plant root and stem anatomy ${ }^{12}$ under salinity stress, the positive effects on the plant leaf anatomy were also determined in the light of statistical evaluation of numerical values. Leaf is the center of metabolic activities in plants. Considering it is effective in seed and fruit yield the leaf of edible plants is very important.

\section{Materials and methods}

\section{Plant material and field trial}

In this study, two different genotypes of Triticum aestivum L., namely G 5907 (Australian origin) and Bayraktar 2000 (Turkish origin), were used. Plants were grown in a growth room at 45$55 \%$ humidity, under 16 hours light and 8 hours dark photoperiod, at $21^{\circ} \mathrm{C}$ temperature and 14,000 lux/day light intensity. Seedlings were exposed to different $\mathrm{NaCl}$ applications and NO. Samples of the treatment groups consisting of six different applications were as follows; 1. Control group harvested at day 0. (Hoagland solution), 2. Nitric oxide control (Hoagland $+100 \mu \mathrm{M}$ Nitric oxide), 3. $\mathrm{NaCl}(50$ $\mathrm{mM})$, 4. Nitric oxide $+\mathrm{NaCl}(50 \mathrm{mM}+\mathrm{NO}), 5 . \mathrm{NaCl}(100 \mathrm{mM}), 6$. Nitric oxide $+\mathrm{NaCl}(100 \mathrm{mM}+\mathrm{NO})$.

\section{Anatomical studies}

For anatomical studies, plant samples were kept in $70 \%$ alcohol. The paraffin method was used to take sections from the leaves of plant samples with microtome. ${ }^{13}$ In addition, handle-blade cross sections were prepared from the leaves using Safranin and Fast green for dyeing the samples. ${ }^{14}$

Anatomical measurements were performed using micrometric ocular, using sections from the leaves. Results were presented by photographs and Tab.s (Figure 1, Table 1). Photographs were taken from the section of plant samples with Leica DM 3000 microscopy. For the numerical analyses, 7 characters of the leaves belong to two different $T$. aestivum genotypes were selected (Table 2).

\section{Statistical studies}

Characters were coded as 1-7 and the genotypes were coded as G 5907 genotype (A) and Bayraktar 2000 genotype (B) (Table 2-4). Significance of the differences between the genotypes and characters were evaluated by Pearson correlation and the results were evaluated statistically by ANOVA test. 


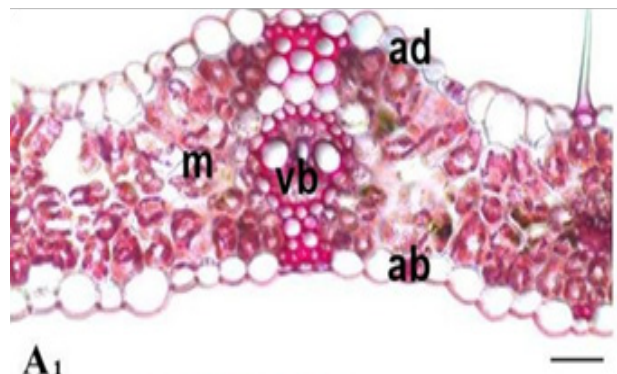

$\mathbf{A}_{1}$

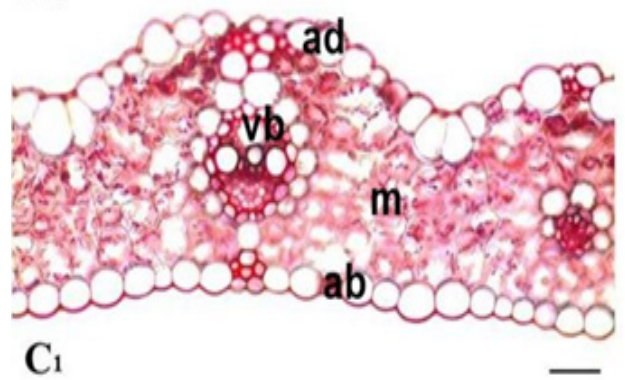

$\mathrm{C}_{1}$

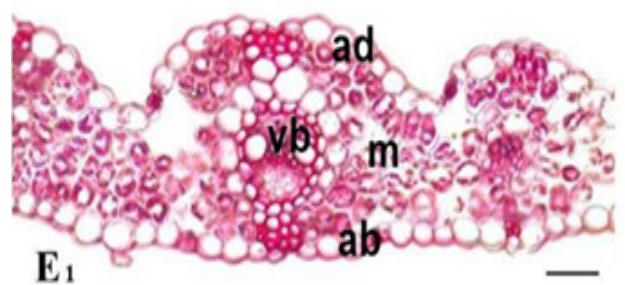

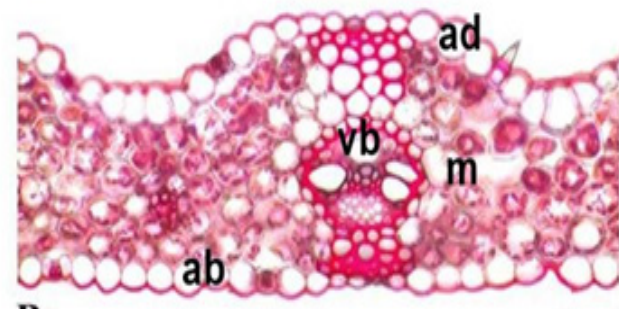

$\mathrm{B}_{1}$

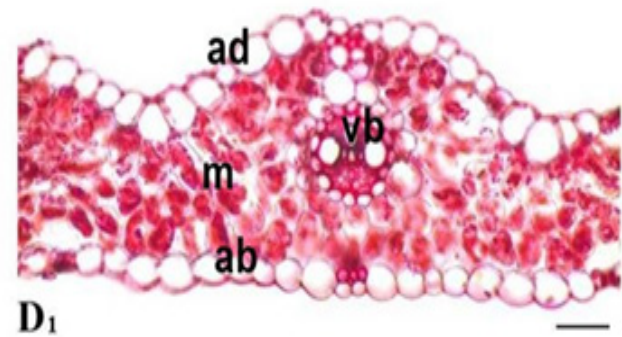

$\mathbf{D}_{1}$

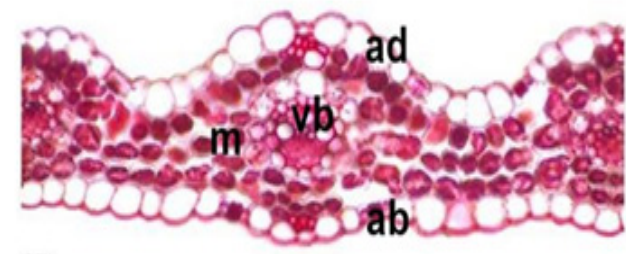

$\mathbf{F}_{1}$

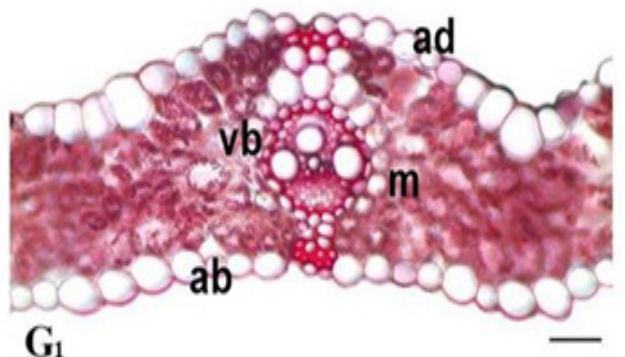

Figure I Cross section of leaves of I. Genotype of bread wheat (G 5907 Australian origin A) under salinity stress (Scale bars $50 \mu \mathrm{m}$ ). ab: abaxial epidermis, ad: adaxial epidermis, m:mesophyll, vb: vascular bundle.

Al: 0. day, BI: Control groups, $\mathrm{Cl}: \mathrm{C}+\mathrm{NO}, \mathrm{DI}: 50 \mathrm{Mm}, \mathrm{EI}: 50 \mathrm{mM} \mathrm{NaCl}+\mathrm{NO}, \mathrm{FI}: 100 \mathrm{mM} \mathrm{NaCl}, \mathrm{GI}: 100 \mathrm{mM} \mathrm{NaCl}+\mathrm{NO}$.

Table I Anatomical measurement of the leaves of G 5907 genotype (A) and Bayraktar 2000 genotype (B)

\begin{tabular}{llllll}
\hline & \multicolumn{2}{c}{ G $\mathbf{5 9 0 7}$ genotype (A) } & \multicolumn{2}{c}{ Bayraktar 2000 genotype (B) } \\
\cline { 2 - 6 } & $\boldsymbol{\mu}$ & Min-Max. & Medium \pm SD & Min-Max. & Medium \pm SD \\
\hline O.day & & & & & \\
Upper Epidermis & Width & $25.29-41.47$ & $31.15 \pm 5.39$ & $13.52-36.17$ & $22.4 \pm 6.71$ \\
& Length & $20.58-34.11$ & $27.48 \pm 4.46$ & $12.35-25.29$ & $18.64 \pm 4.06$ \\
& Width & $19.11-44.11$ & $31.29 \pm 6.83$ & $19.4-78.52$ & $46.36 \pm 19.7$ \\
Mesophyll & Length & $20.95-60.58$ & $40.15 \pm 13.8$ & $17.64-54.7$ & $27.23 \pm 9.8$ \\
Trachea & Diam. & $17.17-38.52$ & $29.61 \pm 6.7$ & $11.17-37.05$ & $22.13 \pm 7.91$ \\
Lower Epidermis & Width & $19.41-47.05$ & $33.96 \pm 8.1$ & $12.94-45.58$ & $31.25 \pm 8.72$ \\
& Length & $19.11-44.1$ & $31.29 \pm 6.83$ & $10.29-33.82$ & $21.91 \pm 6.33$ \\
\hline
\end{tabular}

Citation: Bozdağ B, Özdemir A, Hamurcu M, et al. Numerical and statistical evaluation of nitric oxide effect on leaf anatomy of Triticum genotypes under salinity stress.J Microbiol Exp. 2020;8(4):I 40-146. DOI: 10.15406/jmen.2020.08.00299 
Table Continued...

\begin{tabular}{|c|c|c|c|c|c|}
\hline & \multicolumn{3}{|c|}{ G 5907 genotype (A) } & \multicolumn{2}{|c|}{ Bayraktar 2000 genotype (B) } \\
\hline & $\mu \mathrm{m}$ & Min-Max. & Medium $\pm S D$ & Min-Max. & Medium \pm SD \\
\hline \multicolumn{6}{|l|}{ Control } \\
\hline \multirow[t]{2}{*}{ Upper Epidermis } & Width & $21.76-36.76$ & $28.62 \pm 4.95$ & $25.29-38.52$ & $32.22 \pm 3.94$ \\
\hline & Length & $16.88-35.58$ & $26.82 \pm 5.97$ & $19.7 \mid-28.23$ & $24.3 I \pm 2.82$ \\
\hline \multirow[t]{2}{*}{ Mesophyll } & Width & $21.76-58.17$ & $38.5 \pm 11.4$ & $19.7-60.88$ & $38.36 \pm 11$ \\
\hline & Length & $20.58-42.35$ & $31.62 \pm 6.94$ & $18.23-52.04$ & $35.63 \pm 10.2$ \\
\hline Trachea & Diam. & $21.47-39.11$ & $28.37 \pm 5.36$ & 13.76-37.94 & $28.0 \mathrm{I} \pm 8.45$ \\
\hline \multirow[t]{2}{*}{ Lower Epidermis } & Width & $20.58-40.29$ & $29.68 \pm 5.11$ & $22.94-40.11$ & $30.98 \pm 4.56$ \\
\hline & Length & $18.23-33.23$ & $25.01 \pm 4.66$ & $17.35-33.8$ & $25.42 \pm 5.18$ \\
\hline \multicolumn{6}{|l|}{$\mathrm{C}+\mathrm{NO}$} \\
\hline \multirow[t]{2}{*}{ Upper Epidermis } & Width & $23.33-44.11$ & $33.1 \pm 5.75$ & $19.7-40.88$ & $32.52 \pm 6.55$ \\
\hline & Length & $20.88-44.11$ & $31.16 \pm 7.84$ & $21.17-44.4 \mid$ & $33.79 \pm 7.01$ \\
\hline \multirow[t]{2}{*}{ Mesophyll } & Width & $22.94-68.82$ & $40.13 \pm 15$ & $18.23-56.74$ & $41.03 \pm 11.1$ \\
\hline & Length & $23.82-44.7$ & $31.89 \pm 6.45$ & $22.35-40.29$ & $33.64 \pm 5$ \\
\hline Trachea & Diam. & I5.29-43.23 & $23.3 \pm 6.42$ & $11.76-32.35$ & $25.2 \pm 5.28$ \\
\hline \multirow[t]{2}{*}{ Lower Epidermis } & Width & $18.23-39.7$ & $30.26 \pm 5.63$ & $23.52-42.05$ & $32.36 \pm 5.74$ \\
\hline & Length & $17.94-40.58$ & $29.79 \pm 6.23$ & $22.94-41.17$ & $33.28 \pm 5.59$ \\
\hline \multicolumn{6}{|l|}{$50 \mathrm{mM} \mathrm{NaCl}$} \\
\hline \multirow[t]{2}{*}{ Upper Epidermis } & Width & 15.85-39.42 & $25.58 \pm 8.16$ & $20.86-47.05$ & $31.95 \pm 7.55$ \\
\hline & Length & $|7.94-39.4|$ & $26.95 \pm 6.84$ & $16.47-38.64$ & $26.18 \pm 5.76$ \\
\hline \multirow[t]{2}{*}{ Mesophyll } & Width & $16.47-55.58$ & $32.59 \pm 10.8$ & $15.58-52.6$ & $33.3 \pm 9.44$ \\
\hline & Length & $15-32.94$ & $25.06 \pm 5.1$ & $14.76-37.17$ & $26.11 \pm 6.54$ \\
\hline Trachea & Diam. & $20-30.29$ & $23.37 \pm 3.6$ & $17.35-27.64$ & $22.99 \pm 3.5$ \\
\hline \multirow[t]{2}{*}{ Lower Epidermis } & Width & $20.82-35$ & $27.5 \pm 4.1$ & $21.47-45.29$ & $31.34 \pm 5.91$ \\
\hline & Length & $21.17-34.38$ & $26.21 \pm 3.9$ & $17.94-36.76$ & $26.23 \pm 5.02$ \\
\hline \multicolumn{6}{|l|}{$50 \mathrm{mM} \mathrm{NaCl}+\mathrm{NO}$} \\
\hline \multirow[t]{2}{*}{ Upper Epidermis } & Width & 12.64-29.37 & $22.77 \pm 4.6$ & $|2.52-34.1|$ & $20.42 \pm 6.61$ \\
\hline & Length & $|4| \mid-27.64$. & $21.66 \pm 4.45$ & $8.23-29.7$ & $18.91 \pm 6.39$ \\
\hline \multirow[t]{2}{*}{ Mesophyll } & Width & 15.29-56.76 & $30.67 \pm 13.02$ & $20.28-47.24$ & $31.63 \pm 8.97$ \\
\hline & Length & |4.7-35.68 & $23.49 \pm 6.59$ & $14.49-29.56$ & $21.92 \pm 4.92$ \\
\hline Trachea & Diam. & $16.47-25.29$ & $20.66 \pm 2.8$ & $19.29-38.23$ & $29.97 \pm 5.25$ \\
\hline \multirow[t]{2}{*}{ Lower Epidermis } & Width & $12.35-28.23$ & $22.52 \pm 4.25$ & $20-32.03$ & $25.35 \pm 3.81$ \\
\hline & Length & $14.4-26.17$ & $20.52 \pm 3.08$ & |4.1|-27.05 & $20.03 \pm 4.37$ \\
\hline \multicolumn{6}{|l|}{$100 \mathrm{mM} \mathrm{NaCl}$} \\
\hline \multirow[t]{2}{*}{ Upper Epidermis } & Width & $18.52-36.76$ & $27.75 \pm 6.7$ & $|2.47-34.1|$ & $20.5 \pm 5.9$ \\
\hline & Length & $16.72-37.05$ & $26.54 \pm 5.57$ & $7.05-29.3$ & $|6.89 \pm 5.7|$ \\
\hline \multirow[t]{2}{*}{ Mesophyll } & Width & |3.5-57.35 & $31.5 \pm 13.94$ & $22.31-45.79$ & $31.89 \pm 5.69$ \\
\hline & Length & $12.09-40.29$ & $25.26 \pm 9.25$ & $19.13-37.97$ & $26.49 \pm 5.4$ \\
\hline Trachea & Diam. & $11.76-17.94$ & $14.68 \pm 2$ & $15.58-26.17$ & $21.05 \pm 3.12$ \\
\hline
\end{tabular}


Table Continued..

\begin{tabular}{|c|c|c|c|c|c|}
\hline & \multicolumn{3}{|c|}{ G 5907 genotype (A) } & \multicolumn{2}{|c|}{ Bayraktar 2000 genotype (B) } \\
\hline & $\mu \mathrm{m}$ & Min-Max. & Medium \pm SD & Min-Max. & Medium $\pm S D$ \\
\hline \multirow[t]{2}{*}{ Lower Epidermis } & Width & $15.58-32.03$ & $22.68 \pm 5.31$ & |4.38-34.35 & $24.69 \pm 6.48$ \\
\hline & Length & $12.05-32.35$ & $20.27 \pm 5.29$ & $11.76-33.52$ & $25.28 \pm 7.21$ \\
\hline \multicolumn{6}{|l|}{$100 \mathrm{mM} \mathrm{NaCl}+\mathrm{NO}$} \\
\hline \multirow[t]{2}{*}{ Upper Epidermis } & Width & $20.55-40.58$ & $27.54 \pm 5.64$ & $|7.64-3| .17$ & $23.99 \pm 3.87$ \\
\hline & Length & $18.23-45$ & $25.97 \pm 6.1$ & 15.29-33.29 & $22.03 \pm 4.7 \mid$ \\
\hline \multirow[t]{2}{*}{ Mesophyll } & Width & |6.76-79.|| & $42.03 \pm 20.38$ & $24.92-48.11$ & $33.27 \pm 6.1$ \\
\hline & Length & $14.52-44.7$ & $27.36 \pm 8.16$ & 17.97-33.33 & $23.68 \pm 4.61$ \\
\hline Trachea & Diam. & II.47-30.58 & $24.75 \pm 5.21$ & 18.6-37.27 & $29.62 \pm 5.71$ \\
\hline \multirow[t]{2}{*}{ Lower Epidermis } & Width & $12-45.49$ & $29.66 \pm 9.71$ & $15.29-35$ & $25.32 \pm 6.68$ \\
\hline & Length & $10-41.76$ & $26.82 \pm 9.78$ & I I.47-32.05 & $22.46 \pm 7.02$ \\
\hline
\end{tabular}

Table 2 Selected anatomical character measurements for statistical studies of G 5907 (A) and Bayraktar 2000 (B)

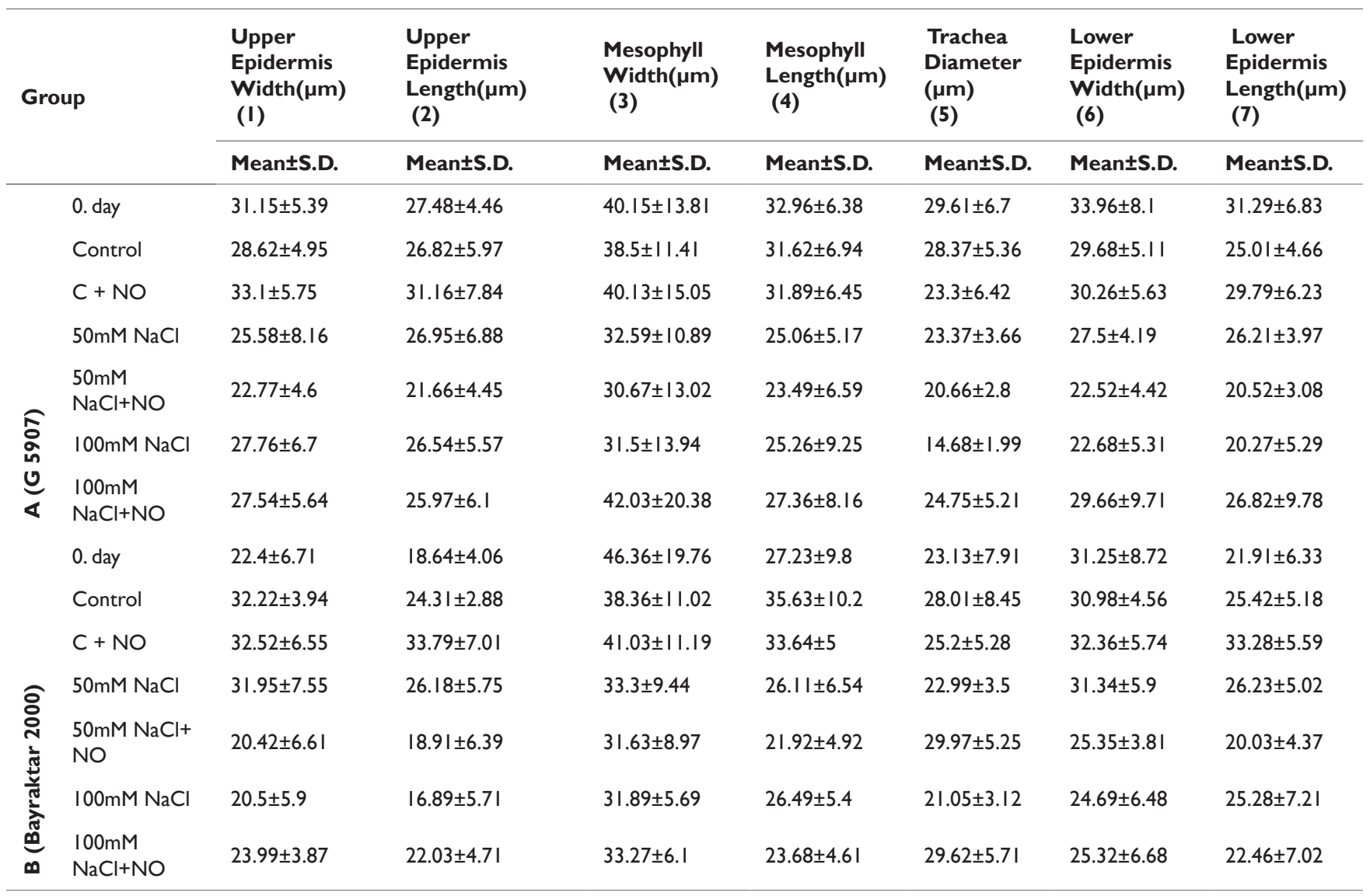

Table 3 Pearson correlation based anatomical characters of the G 5907 (A)

\begin{tabular}{lllllll}
\hline & I & $\mathbf{2}$ & $\mathbf{3}$ & $\mathbf{4}$ & $\mathbf{5}$ & $\mathbf{6}$ \\
\hline $\mathbf{2}$ & 0.887 & & & & \\
& $0.008^{* *}$ & & & & \\
$\mathbf{3}$ & 0.843 & 0.728 & & & \\
& 0.056 & 0.064 & & & \\
4 & 0.525 & 0.734 & 0.604 & & \\
& 0.226 & 0.06 & 0.151 & & \\
\hline
\end{tabular}

Citation: Bozdağ B, Özdemir A, Hamurcu M, et al. Numerical and statistical evaluation of nitric oxide effect on leaf anatomy of Triticum genotypes under salinity stress. J Microbiol Exp. 2020;8(4): I40-I46. DOI: I0.15406/jmen.2020.08.00299 
Table Continued...

\begin{tabular}{lllllll}
\hline & $\mathbf{I}$ & $\mathbf{2}$ & $\mathbf{3}$ & $\mathbf{4}$ & $\mathbf{5}$ & $\mathbf{6}$ \\
\hline $\mathbf{5}$ & 0.93 & 0.895 & 0.938 & 0.966 & & \\
& $0.002^{* *}$ & $0.007^{* *}$ & $0.002^{* *}$ & $0.00 I^{* *}$ & & \\
$\mathbf{6}$ & 0.597 & 0.869 & 0.644 & 0.845 & 0.846 & \\
& 0.062 & 0.011 & 0.061 & 0.052 & 0.052 & \\
$\mathbf{7}$ & 0.872 & 0.755 & 0.614 & 0.457 & 0.668 & 0.846 \\
& 0.05 & 0.142 & 0.303 & 0.197 & 0.101 & 0.017 \\
\hline
\end{tabular}

**Significant at the level of 0.0I. ( 1-7: Character Codes)

Table 4 Pearson correlation based anatomical characters of the Bayraktar 2000 (B)

\begin{tabular}{lllllll}
\hline & $\mathbf{I}$ & $\mathbf{2}$ & $\mathbf{3}$ & $\mathbf{4}$ & $\mathbf{5}$ & $\mathbf{6}$ \\
\hline $\mathbf{2}$ & 0.808 & & & & & \\
& $0.028^{*}$ & & & & & \\
$\mathbf{3}$ & 0.729 & 0.582 & & & & \\
& 0.063 & 0.171 & & & & \\
$\mathbf{4}$ & 0.671 & 0.605 & 0.714 & & & \\
& 0.099 & 0.15 & 0.071 & & & \\
$\mathbf{5}$ & 0.893 & 0.957 & 0.872 & 0.872 & & \\
& $0.007 * *$ & $0.001 * *$ & $0.010 *$ & $0.010 * *$ & & \\
6 & 0.707 & 0.51 & 0.093 & 0.179 & 0.554 & \\
& 0.075 & 0.242 & 0.843 & 0.7 & 0.011 & \\
\hline $\mathbf{7}$ & 0.725 & 0.582 & 0.256 & 0.297 & 0.82 & 0.584 \\
& 0.054 & 0.17 & 0.58 & 0.518 & 0.015 & 0.169 \\
\hline
\end{tabular}

*Significant at the level of 0.05 . **Significant at the level of 0.01. ( I-7: Character Codes)

\section{Results and discussion}

\section{Anatomical analysis}

According to results from anatomical studies, the most affected tissues from nitric oxide (NO) under salinity stress were the vascular tissues in the leaves of both genotypes. The cross sections of the leaf samples for G 5907 and Bayraktar 2000 varieties revealed that measured values vary considerably in different applications. NO led to the narrowing in the leaf syclerenchymatic tissue of G 5907 and Bayraktar 2000 varieties while enlargement in the tracheal diameter of the leaves were observed (Figure 1,2). Özdemir et al., ${ }^{12}$ reported remarkable increase on the number of root xylem for both the control samples with $\mathrm{NO}(\mathrm{C}+\mathrm{NO})$ and $50 \mathrm{mM} \mathrm{NaCl}+\mathrm{NO}$ applications of Triticum aestivum L. genotypes. Similar results were encountered in this study for the anatomical structures of the leaves of the genotypes under investigation. However, the trachea cell diameters of both genotypes have narrowed in $100 \mathrm{mM}$ salt application. Mesophyll tissues were highly variable and consist of larger cells in $100 \mathrm{mM}$ $\mathrm{NaCl}+\mathrm{NO}$ applications. Mesophyll cells with smallest diameter were observed in $100 \mathrm{mM} \mathrm{NaCl}$ applications. This may provide evidence on the effects of $\mathrm{NO}$ under saline conditions where the cells exhibit sudden changes in their sizes. Trachea cells have narrowed in 100 $\mathrm{mM}$ salt applications. It was determined that the measurements of the stem epidermis of T. aestivum genotypes grown under application of $50 \mathrm{mM} \mathrm{NaCL}$ and $100 \mathrm{mM} \mathrm{NaCl}+\mathrm{NO}$ were less effected compared with the previous data where the epidermal measurements of the stem samples of NO applications were lesser than control group. ${ }^{12}$ In this study, Similar results were found for the anatomical structures of the leaves of the investigated genotypes. In $\mathrm{NO}$ application $(\mathrm{C}+\mathrm{NO})$ of the previous study, upper epidermis layer was thickened and mesophyll region was enlarged at G 5907 and Bayraktar 2000. In this application, NO may have triggered the thickening of the cell walls and the storing water. The only decrease we found for the thickness of the mesophyll was in samples of $100 \mathrm{mM} \mathrm{NaCl}$ applications, while the remaining samples were all exhibited increases on the thickness of the mesophyll region with increased salt concentrations. Mesophyll region expansions were more prominent on the samples of the G 5907 and Bayraktar 2000 varieties grown under $\mathrm{C}+\mathrm{NO}$ application (Figure $1,2)$.

\section{Statistical analysis}

The leaves anatomical measurements of the investigated bread wheat genotypes were shown in Table 1. Selected anatomical character measurements for statistical studies of G 5907 (A) and Bayraktar 2000 (B) were shown in Table 2. Significance of the differences between the two genotypes were evaluated using Pearson correlation. The results of the statistical analyses were presented in Table 3 \& 4. As shown in Table 2 and Table 3, significance of the differences (at the level of 0.01) for the characters of trachea (diameter) were determined (coded as 5) in both of the genotypes. By the analyses 
of the investigated wheat genotypes with different salinity responses among the seven leaf anatomy related characters, it was determined that trachea diameter and upper epidermis width are the best character pairs which represent clearly the variations. According to the statistical results derived, trachea diameters and the different salinity levels of the two genotypes investigated exhibited considerable relationship, at the level of $\mathrm{P}<01$ and $\mathrm{P}<0.05$, respectively. These statistical results support the findings of the leaf anatomical characters of both genotypes. Hence, it can be speculated that the results from statistical analysis of leaf anatomy characters of the investigated genotypes under salinity conditions can provide distinct numerical evidences on the responses of the two genotypes against salinity. However G 5907 is a genotype empowered with an extra salt tolerance gene ( $\operatorname{Nax} 1)$ derived from the wheat progenitor Triticum monococcum L. (AA), it should be denoted that both of the genotypes are hexaploid and have intrinsically a functional Knal locus on their D genome (a character located on the long arm of chromosome 4D), a trait that makes bread wheat more tolerant against salt stress, compared with durum wheat that lacks a D genome. Based on this, durum wheats (AABB) have higher rates of $\mathrm{Na}+$ accumulation and poor $\mathrm{K}+\mathrm{Na}+$ discrimination. Yet, both Naxl and Knal are likely to be $\mathrm{Na}+$ transporters in subfamily 1 of the HKT (High-affinity K+ Transporter) gene family. ${ }^{15,16}$ The candidate gene for Nax 1 is HKT1;4-A2 $2^{17}$ and for Kna1 is HKT $1 ; 5-\mathrm{D},{ }^{18}$ both genes providing a certain level of tolerance against salinity. Nax 1 has an additive effect to Knal by further lowering the leaf $\mathrm{Na}+$ concentration. ${ }^{19,20}$

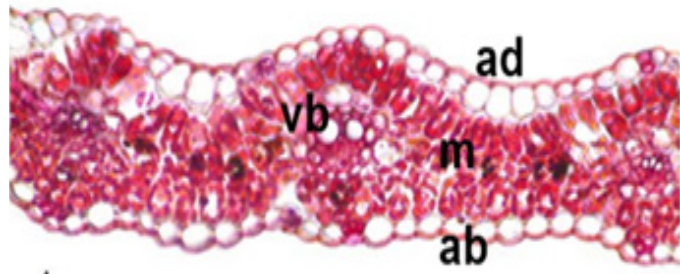

$\mathrm{A}_{2}$

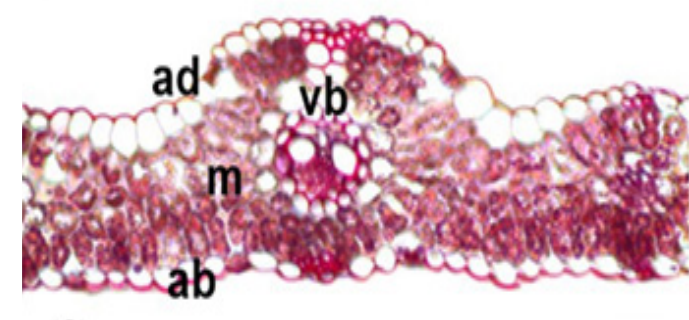

$\mathrm{C}_{2}$

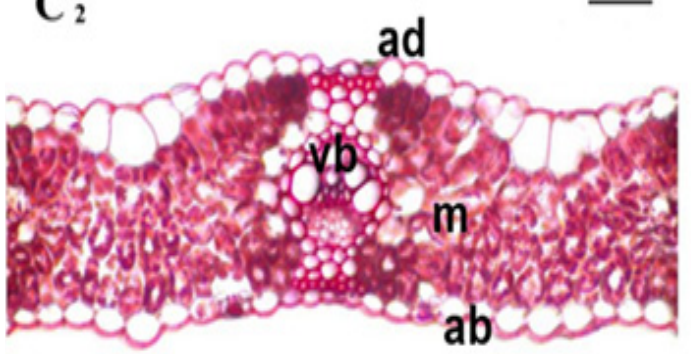

$\mathbf{E}_{2}$

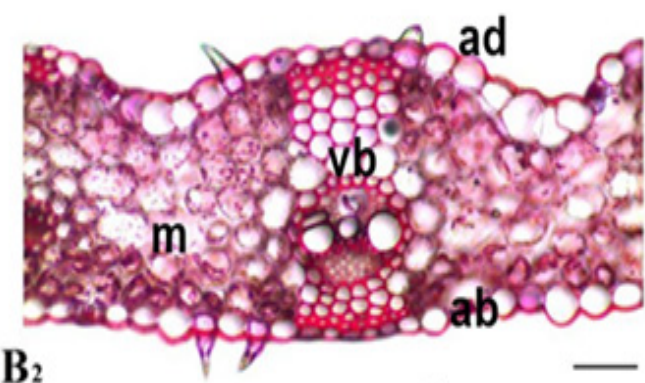

$\mathrm{B}_{2}$
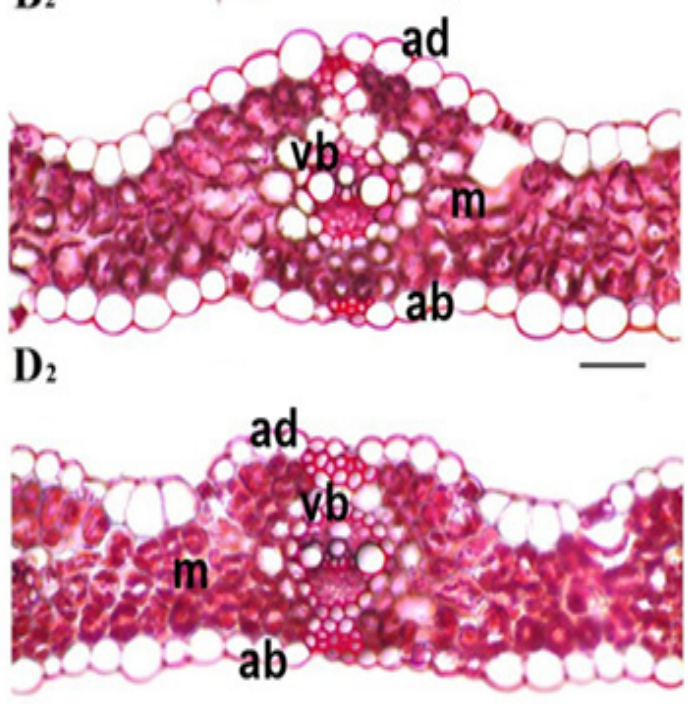

$F_{2}$

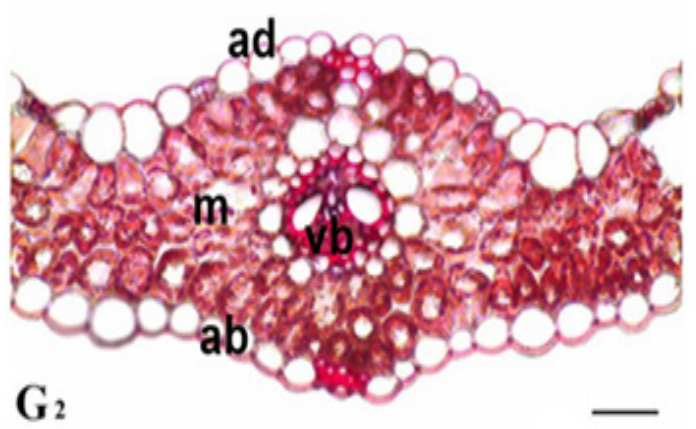

Figure 2 Cross section of leaves of 2. Genotype wheat (Bayraktar 2000 Turkish origin B) under salinity stress (Scale bars $50 \mu \mathrm{m}$ ). ab: abaxial epidermis, ad: adaxial epidermis, m:mesophyll, vb: vascular bundle.

A2: 0. day, B2: Control groups, C2: C + NO, D2: $50 \mathrm{mM} \mathrm{NaCl}$, E2: $50 \mathrm{mM} \mathrm{NaCl}+\mathrm{NO}, \mathrm{F} 2: 100 \mathrm{mM} \mathrm{NaCl}, \mathrm{G} 2: 100 \mathrm{mM} \mathrm{NaCl}+\mathrm{NO}$. 
Free radicals in plants are formed by the effect of stressors in the environment. Nitric oxide was proven to be intrinsically produced by plant as a signaling molecule that requires intensification of research on its role, especially under stressed conditions. NO was classified as a phytohormone that might function as a gaseous endogenous plant growth regulator. ${ }^{21-23}$ In this study, we observed that leaf cells of both varieties are expanding in both $50 \mathrm{mM} \mathrm{NaCl}+\mathrm{NO}$ and $100 \mathrm{mM}+\mathrm{NO}$ applications while the leaf cells were considerably narrowed in 100 $\mathrm{mM}$ pure salt application .In this study, it was aimed to determine the potential effects of nitric oxide on the leaves of the two bread wheats grown under salinity stress using the support of numerical data. Since leaf is the place where metabolic activity occurs, it is very important in terms of crop yield. In this study, we found that NO, which may be used to ameliorate the effects of salinity stress on plants, causes significant changes in leaf anatomy of the two bread wheat genotypes examined. The statistical evaluations conducted in the study also supported this evaluation.

\section{Acknowledgments}

We acknowledge CSIRO for providing G 5907 line containing Nax 1 trait. We also acknowledge The Scientific and Technological Research Council of Turkey (TUBITAK Project No. 214O072-2018) and Selçuk University (S.U. BAP-16401074-2018) for the financial supports of this research.

\section{Conflicts of interest}

Authors declare that there is no conflict of interest.

\section{References}

1. Carlos GM, Lorenzo L. Nitric Oxide Induces Stomatal Closure and Enhances the Adaptive Plant Responses against Drought Stress. Plant Physiology. 2001;126(3):1196-1204.

2. Çelik A, Eraslan F. Nitrik Oksit Uygulamasının Tuz Stresi Altında Yetiştirilen Mısır Bitkisinin Mineral Beslenmesi ve Bazı Fizyolojik Özellikleri Üzerine Etkisi. Süleyman Demirel Üniversitesi Ziraat Fakültesi Dergisi. 2015;10(1):55-64.

3. Bolwell GP. Role of reactive oxygen species and NO in plant defence responses. Curr Opin Plant Biol. 1999;152(2):287-294.

4. Beligni MV, Lamattina L. Is nitric oxide toxic or protective. Trends Plant Sci. 1999;4(8):299-300.

5. Wendehenne D, Pugin A, Klessig DF, et al. Nitric oxide: comparative synthesis and signaling in animal and plant cell. Trends in Plant Science. 2001;6(4):177-183

6. Neill S, Barros R, Bright J, et al. Nitric oxide, stomatal closure, and abiotic stress. Journal Experimental Botany. 2008;59(2):165-176.

7. Lamattina L, Garcia-Mata C, Graziano M, et al. Nitric oxide: The versality of an extensive signal molecule. Annual Review of Plant Biology. 2003;54:109-136.
8. Xu Z, Zhong S, Li X, et al. Genome-wide identification of microRNAs in response to low nitrate availability in maize leaves and roots. PLoS One. 2011;6(11):e28009

9. Poljakoff-Mayber A. Morphological and anatomical changes in plants as a response to salinity stress. Plants in Saline Environments; 1975. 97-117 p.

10. Casenave EC, Degano CA, Toselli ME, et al. Statistical studies on anatomical modifications in the radicle and hypocotyl of cotton induced by $\mathrm{NaCl}$. Biological Research. 1999;32(4):289-295.

11. Çavuşoğlu K, Kılıç S, Kabar K. Effects of some plant growth regulators on stem anatomy of radish seedlings grown under saline $(\mathrm{NaCl})$ conditions Plant Soil Environment. 2008;54(10):428-433.

12. Özdemir C, Hamurcu M, Akyol Y, et al. Effect of nitric oxide on the anatomy of two Triticum aestivum L. genotypes under salinity stress and statistical evaluation. Advances in Food Sciences. 2017;39:14-21.

13. Algan G. Microtechnics for plant tissues. PhD Thesis. Firat University, Faculty of Science, Istanbul, Turkey; 1981.

14. Bozdağ B, Kocabaş O, Akyol Y, et al. Bitki Anatomisi Çalışmalarında El Kesitleri İçin Yeni Boyama Yöntemi. Marmara Pharmaceutical Journal. 2016;20(2):184-190.

15. James RA, Davenport R, Munns R. Physiological characterisation of two genes for $\mathrm{Na}+$ exclusion in durum wheat: $\mathrm{Nax} 1$ and Nax2. Plant Physiology. 2006;142(4):1537-1547.

16. James RA, Blake C, Byrt CS, et al. Major genes for $\mathrm{Na}+$ exclusion Nax1 and Nax2 (wheat HKT1;4 and HKT1;5) decrease $\mathrm{Na}+$ accumulation in bread wheat under saline and waterlogged conditions. Journal of Experimental Botany. 2011;62(8):2939-2947.

17. Huang S, Spielmeyer W, Lagudah ES, et al. A sodium transporter (HKT7) is a candidate for Nax1, a gene for salt tolerance in durum wheat. Plant Physiology. 2006;142(4):1718-1727.

18. Byrt C, Platten JD, Spielmeyer W, et al. HKT1;5-like cation transporters linked to $\mathrm{Na}+$ exclusion loci in wheat, $\mathrm{Nax} 2$ and Kna1. Plant Physiology 2007;143(4):1918-1928.

19. James RA, Blake C, Zwart AB, et al. Impact of ancestral wheat sodium exclusion genes Nax1 and Nax2 on grain yield of durum wheat on saline soils. Functional Plant Biology. 2012;39:609-618.

20. Munns R, James RA, Xu B, et al. Wheat grain yield on saline soils is improved by an ancestral $\mathrm{Na}+$ transporter gene. Nature Biotechnology. 2012;30(4):360-364.

21. Wildt J, Kley D, Rockel P, et al. Emission of NO from several higher plant species. Journal of Geophysical Research. 1997;102(D5):5919-5927.

22. Lazalt AM, Beligni VM, Lamattina L. Nitric oxide preserves the level of chlorophyll in potato leaves infected by Phytophthora infestans. European Journal of Plant Patholology. 1997;103:643-651.

23. Leshem YY. Nitric Oxide in Plants: Occurrence, Function and Use. Kluwer Academic Publishers: Dordrecht, Netherlands; 2000. 